\title{
Organizations in Changing Environments: The Case of East German Symphony Orchestras
}

\section{Citation}

Allmendinger, Jutta, and J. Richard Hackman. 1996. Organizations in changing environments: the case of East German symphony orchestras. Administrative Science Quarterly 41, no. 3: 337-369.

\section{Published Version}

http://dx.doi.org/10.2307/2393935

\section{Permanent link}

http://nrs.harvard.edu/urn-3:HUL.InstRepos:3168791

\section{Terms of Use}

This article was downloaded from Harvard University's DASH repository, and is made available under the terms and conditions applicable to Other Posted Material, as set forth at http:// nrs.harvard.edu/urn-3:HUL.InstRepos:dash.current.terms-of-use\#LAA

\section{Share Your Story}

The Harvard community has made this article openly available.

Please share how this access benefits you. Submit a story.

\section{Accessibility}




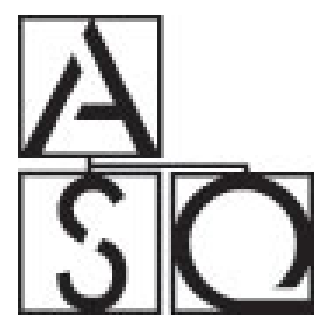

Organizations in Changing Environments: The Case of East German Symphony Orchestras Author(s): Jutta Allmendinger and J. Richard Hackman

Source: Administrative Science Quarterly, Vol. 41, No. 3 (Sep., 1996), pp. 337-369

Published by: Johnson Graduate School of Management, Cornell University

Stable URL: http://www.jstor.org/stable/2393935

Accessed: 06/07/2009 05:28

Your use of the JSTOR archive indicates your acceptance of JSTOR's Terms and Conditions of Use, available at http://www.jstor.org/page/info/about/policies/terms.jsp. JSTOR's Terms and Conditions of Use provides, in part, that unless you have obtained prior permission, you may not download an entire issue of a journal or multiple copies of articles, and you may use content in the JSTOR archive only for your personal, non-commercial use.

Please contact the publisher regarding any further use of this work. Publisher contact information may be obtained at http://www.jstor.org/action/showPublisher?publisherCode=cjohn.

Each copy of any part of a JSTOR transmission must contain the same copyright notice that appears on the screen or printed page of such transmission.

JSTOR is a not-for-profit organization founded in 1995 to build trusted digital archives for scholarship. We work with the scholarly community to preserve their work and the materials they rely upon, and to build a common research platform that promotes the discovery and use of these resources. For more information about JSTOR, please contact support@jstor.org.

Johnson Graduate School of Management, Cornell University is collaborating with JSTOR to digitize, preserve and extend access to Administrative Science Quarterly. 
Organizations in

Changing

Environments: The

Case of East German

Symphony Orchestras

\section{Jutta Allmendinger}

Munich University

J. Richard Hackman

Harvard University
(C) 1996 by Cornell University. 0001-8392/96/4103-0337/\$1.00

Portions of the research reported here were supported by the Max Planck Institute für Bildungsforschung and by the Harvard Graduate School of Business Administration. We thank Larissa

Kowal-Wolk, Erin Lehman, and Rebecca Roters for their collaboration on the project; Jay Tucker for help in translating and coding research materials; and Ben

Dattner, Adam Galinsky, and Tuck

Pescosolido for assistance in library research and data analysis. Helpful comments on this paper were provided by Judith Blau, Hannah Brückner

Thomas Ertman, Paul DiMaggio, Connie Gersick, Stephan Liebfried, Andy

Molinsky, Francie Ostrower, Charles

Perrow, Klaus Jürgen Peter, and Aage

Sorensen. Assistance in enumerating the population of orchestras and in gaining access to those selected for the research was provided by the American Federation of Musicians (AFM), the American

Symphony Orchestra League (ASOL), the Arts Council of Great Britain (ACGB), the European Conference of Symphony Orchestras (ECSO), the International Conference of Symphony and Opera Musicians (ICSOM), and the Regional Orchestra Players Association (ROPA)

We give special thanks to Kenneth Baird (ACGB), Brad Buckley (ICSOM).

Rosemary Estes (ROPA), Catherine

French (ASOL), Ken Haas (Boston

Symphony Orchestra), and Lew Waldeck (AFM).
Two periods of radical political-economic change in the former East Germany illuminate dynamics of organization-environment relationships that generally are hidden from view. Historical, qualitative, and survey data from a longitudinal comparative study of 78 orchestras in four nations show that the contexts of East German orchestras changed significantly when the socialist regime took power after World War II, and then again in 1990 when that regime fell. Socialist rule only modestly affected orchestras' institutional features, however; they continued to reflect centuries-old German musical traditions. The collapse of socialism in 1990, by contrast, provoked differentiation among orchestras-some adapted successfully to the new political-economic context, but others floundered. Successful adaptation was found to be a joint function of an orchestra's prior strength as an organization and the kinds of leadership initiatives taken by orchestra leaders and players. Overall, the findings suggest that the size and character of environmental effects depend on the degree to which contextual changes alter (a) the strength of the link between organizational actions and resources obtained (resource contingency) and (b) organizations' latitude to manage their own affairs (operational autonomy).

In the decades since Stinchcombe's (1965) landmark statements on the relationship between organizations and their societal contexts, an abundant research and theoretical literature on organization-environment relationships has developed. In this paper, we take a fresh look at those relations in historically unique circumstances-specifically, during the two periods of radical political-economic change that occurred in the former East Germany in the last half-century. The first change took place in the years immediately after World War II when the socialist regime took power; the second occurred in 1990 when that regime fell and the German states reunified. Our focal institution is the professional symphony orchestra, which has been integral to East German culture for over a century. By examining the impact of the two revolutionary changes on this deeply rooted cultural institution, we seek to identify and illuminate dynamics of organization-environment relationships that generally are hidden from scholarly view.

There is no dearth of conceptual models of organizationenvironment relations (for a brief review, see Allmendinger and Hackman, 1994). Institutional models (Meyer and Rowan, 1977; Zucker, 1977; DiMaggio and Powell, 1983; Scott, 1987) describe the processes by which organizations situated in similar environments tend to become isomorphic with those environments, increasingly similar to one another, and persistent over time. Population ecology models (Hannan and Freeman, 1977, 1989; Aldrich, 1979) explain how environmental changes reshape the population of organizations in a domain. Over time, organizations that fit well with their environments prosper and reproduce, whereas those that do not eventually die out. In the population ecology view, there is little that organizational actors can do to alter ecological forces or to adapt to them. Adaptation models, such as organization-environment fit 
theory (Lawrence and Lorsch, 1967; Thompson, 1967), resource dependency theory (Salancik and Pfeffer, 1977; Pfeffer and Salancik, 1978), and models of organizational responses to threat and failure (Staw, Sandelands, and Dutton, 1981; Meyer, 1982; Haveman, 1992; Ocasio, 1995), derive from a conception of organizations as rational actors (Barnard, 1938; Child, 1972). Although adaptation models vary in the strength of their presumption of managerial rationality-in their view of organizational action as instrumental or mainly symbolic and in their relative focus on actions that are internally or externally oriented-a common theme in these models is that leaders can do constructive things to help their organizations respond appropriately to environmental changes.

All of these approaches can provide useful explanations of organization-environment relationships. Despite the fact that they sometimes generate incompatible predictions, and despite the occasional attempts by scholars to pit them against one another (Singh, House, and Tucker, 1986; Zucker, 1987: 457-459; Astley and Van de Ven, 1983), they are not directly competing theories (Hambrick and Finkelstein, 1987: 370). We view them, instead, as likely to be differentially useful in explaining organization-environment relations in different historical and organizational circumstances. As Gersick (1994: 11) noted, now may be the time to cease asking whether or not organizations adapt or managerial choices matter and to focus instead on "when and how organizations steer successfully through changing environments" (emphasis added).

The overall aim of the present study is to identify the times and circumstances under which significant environmental changes engender institutional dynamics or ecological processes or adaptive initiatives by affected organizations. We draw on quantitative, observational, archival, and interview data about professional symphony orchestras in the former East Germany-supplemented by parallel data from orchestras in the former West Germany, the United Kingdom, and the United States-to do this.

Symphony orchestras in East Germany provide a uniquely appropriate setting for this analysis because they experienced in this century two episodes of radical societal change-both well defined but invoking opposite social policies-separated by a long intervening period of relative social stability. The experience of East German orchestras between 1945 and 1990 has many of the features of a naturally occurring experiment. State central control was introduced after 1945, allowed to run for over 40 years, and then abruptly dismantled in 1990. There are, moreover, several nonequivalent control groups available for use in interpreting findings from East German orchestras-those in West Germany, which have the same musical tradition as orchestras in East Germany but, after 1945, a sharply different political-economic context; and those in other Western nations, which share with East German orchestras neither musical tradition nor political-economic context.

\section{Research Focus}

We approach our overall research agenda of identifying the kinds of processes set in motion by significant 
environmental change by first disaggregating the problem into three more specific and empirically tractable queries. Then, after we have reported what our data have to say about these questions, we integrate the findings into a new conceptual framework for analyzing how organizations respond to changing environments.

1. Did regulatory agencies and/or local governments buffer East German orchestras from the impact of national political and economic changes?

That major political-economic changes occurred in Germany after World War II and again in 1990 is evident in the historical record. It does not necessarily follow, however, that those national-level jolts were felt with full force by East German symphony orchestras. Any national regime necessarily implements its social and economic policies through a variety of administrative and regulatory agencies, which form the proximal context of operating organizations (Carroll, Delacroix, and Goodstein, 1988). It is possible for these agencies to absorb the impact of even radical national-level changes, leaving the proximal environment of regulated organizations mostly unchanged (Aldrich, 1979: 196). We draw on qualitative and historical data to determine whether the proximal environment of East German orchestras actually did change after 1945 or in 1990-or whether mid-range government entities blunted or redirected national policies in ways that preserved orchestras' traditional operating environments.

2. To what extent, and in what ways, did orchestral functioning and the life and work of orchestra players change in response to the two national-level political-economic changes?

Symphony orchestras in East Germany are strong and deeply rooted cultural institutions. Even if their proximal environments were altered by the two rounds of political-economic changes in that country, institutional forces might have been strong enough for orchestras to weather the changes. If so, we would expect to find orchestras persisting in their traditional ways of operating and few changes in the life and work of orchestra players following the societal-level shocks. Alternatively, the societal changes may have been strong and pervasive enough to overcome inertial forces and recast the very institutional form of the East German symphony orchestra. We draw on quantitative data from orchestras and players to assess empirically what happens when radical political-economic changes collide with strong institutional forces.

3. What factors distinguish those orchestras that adapted successfully to the potentially threatening political-economic changes in East Germany from those that did not?

A changing external environment always offers the possibility of adaptation in which opportunities for improvement are exploited or, at least, potential negative consequences of the changes are avoided. Some orchestras in East Germany fared better after the dismantling of the socialist state in 1990 than did others. We draw on both quantitative and qualitative data to distinguish between these two groups of orchestras. Specifically, we empirically explore the possibility that successful adaptation depends jointly on (a) an organization's strength prior to the 
contextual shock and (b) the kinds of leadership initiatives taken by organization managers and members.

Trustworthy answers to these three research questions would contribute to sociological knowledge about cultural institutions as well as to organization theory. Although there has been considerable research on how cultural traditions and political-economic factors affect public support for cultural institutions (Blau, 1988, 1989), less is known about contextual influences on the organizations that actually produce cultural products. Because of the extraordinary variation in the societal context of East German orchestras over the last four decades, East Germany offers a unique setting for assessing factors that affect the viability of cultural organizations. Moreover, because symphony orchestras, relative to other cultural institutions, tend to be insulated from direct political and ideological influence (Shostakovich, 1983), any findings of effects from political changes are likely to be conservative. Rueschemeyer's (1991) research on East German visual arts and Goldfarb's (1980) study of Polish student theater supplement the results reported here by providing tests of the relation between political systems and more politically sensitive cultural forms.

\section{Research Setting and Strategy}

Symphony orchestras. Professional symphony orchestras are defined as ensembles whose primary mission is public performance of those orchestral works generally considered to fall within the standard symphonic repertoire and whose members are compensated nontrivially for their services. Both concert and broadcast orchestras fall within our domain, as do orchestras that perform specialized works such as operas or pops programs in addition to the standard repertoire. Excluded are chamber ensembles, orchestras that perform operatic or theater works exclusively, university orchestras, and amateur orchestras.

The core task of symphony orchestras is well defined and similar both within and across nations, in that symphony orchestras around the world play largely the same repertoire with roughly the same number and mix of players. By including in our domain only orchestras that perform the standard symphonic repertoire, most task-based variance is automatically controlled. This reduces the problem, common in comparative research, that differences in tasks or composition are confounded with organizational or national contexts.

German orchestras. Orchestral music in Germany has received much public attention and consistent financial support over the last 200 years (Pfannkuch, 1962; Weineck, 1985). In the eighteenth century, orchestras were supported mainly by the nobility; by the twentieth century, almost all funding was provided by states and municipalities (Becker, 1962; Raynor, 1978), supplemented by limited federal funds and occasional private donations for special projects. The state also was the dominant provider of musical training, with music schools and conservatories spread throughout the land. The state-centered support for music in Germany contrasts sharply with the situation in the other two 


\section{Symphony Orchestras}

countries in our sample. During the period addressed in our research (1945-1991), most symphony orchestras in the United Kingdom and almost all orchestras in the United States were freestanding entities, subject to the vagaries of market forces and private philanthropy (DiMaggio and Useem, 1983: 200; Martorella, 1983: 282).

Churches also played an important role in promoting musical culture in Germany by supplementing state-provided musical training, encouraging the composition of new works, and supplying regular audiences for performances. With sustained government support, widespread opportunities for musical training, a continuous flow of new compositions, and numerous performance venues, symphonic music became part of the cultural fabric of the land. People from all strata of German society, not just the elite, were familiar with symphonic music and accustomed to hearing it routinely in their own communities.

This pattern persisted through many periods of political and economic turbulence, including even the Nazi regime (Prieberg, 1982). The pattern changed abruptly in 1945, however, when Germany was partitioned, and each nation began to go its own way. That musical culture continued to be important to both German states in the ensuing historical period is not in question. The question, instead, is to what extent-and in what ways-East German orchestras and their proximal contexts changed after 1945 and then again in the late 1980s.

Analytic strategy. Archival, interview, observational, and survey data about orchestras and their contexts were collected in 1990 and 1991 as part of a comparative study of 78 symphony orchestras in four nations. We rely on different subsets of those data for each of our three research questions.

For the first question, on the degree to which mid-range government entities buffered orchestras from the full impact of societal-level changes, we draw mainly on archival and interview data. We document changes in the immediate context of East German orchestras that resulted from the advent of the socialist regime following World War II and those that occurred as the events leading to German reunification began to unfold in the late 1980s.

For the second question, on how orchestras and players responded to the societal-level changes, we rely on survey and interview data. To assess the impact of socialism, we draw mainly on survey data collected from members of orchestras in the four countries in our sample as the communist era came to an end in early 1990 . If four decades of socialist policies and practices had significantly affected East German orchestras, then the reports of players in those orchestras should differ substantially both from those of their counterparts in West German orchestras (which, during the same historical period, operated in a democracy that became increasingly market-oriented) and from those of musicians in the two English-speaking nations. To assess the impact of the second major political-economic change, we collected an additional wave of survey data in the summer of 1991, after the socialist regime had fallen. 
These data allow us to track directly the impact of this second change on orchestras and players.

For the third question, about the factors that distinguish orchestras that prospered under reunification from those that began to flounder, we rely on survey, interview, and observational data. These data identify certain structural features of orchestras and patterns of behavior by orchestra leaders and members that moderated the impact of reunification on orchestras and players. Throughout, we give special attention to mechanisms that cross levels of analysis-particularly to the interactions among (a) contextual factors (the two political-economic shocks and government policies and practices), (b) organization-level variables (structural features of orchestras), and (c) the behavior and attitudes of individual players and leaders.

\section{METHOD}

\section{Selection of Orchestras}

The population of symphony orchestras in each of the four countries was enumerated by listing all orchestras that advertised at least one open player position between 1985 and 1989. We obtained the 1989 player salary budget for each of those orchestras and used the distribution of salary budgets to select approximately equal numbers of "major" and "regional" orchestras from each country. Major orchestras were randomly drawn from the top decile (or, in the United Kingdom, which had relatively fewer orchestras, quintile) of the distribution; regional orchestras were randomly drawn from each of the remaining deciles (or quintiles) until we obtained a sample of about 20 orchestras from each country. Of the 81 orchestras invited to participate in the study, 78 agreed (96 percent). One regional orchestra in the United States and one major and one regional orchestra in the United Kingdom declined.

Characteristics of the orchestras in the sample are summarized in Table 1. A number of differences across nation and orchestra standing (major vs. regional) are evident. Only in the United States do all orchestras perform concerts exclusively. The United Kingdom and the two German nations have several orchestras whose main mission is broadcast performances. Only half of the German orchestras perform concerts exclusively; many also perform for opera and theater productions. As might be expected, given their multiple missions, the mean size of German orchestras is larger than that of orchestras in the two English-speaking countries. Regional orchestras in all countries tend to be more recently founded than major orchestras, to have a larger percentage of women players (especially in the United States and the United Kingdom), and (for East and West Germany only) to have a larger percentage of foreign workers. There are no major differences across nations in player demographics.

\section{Qualitative and Archival Data}

Before beginning fieldwork, we studied published information such as orchestra histories, scholarly papers, and newspaper or magazine articles about orchestras in each 
Table 1

Characteristics of Orchestras by Country and Standing

\begin{tabular}{|c|c|c|c|c|c|c|c|c|}
\hline \multirow[b]{2}{*}{ Characteristic } & \multicolumn{2}{|c|}{ East Germany } & \multicolumn{2}{|c|}{ West Germany } & \multicolumn{2}{|c|}{ United States } & \multicolumn{2}{|c|}{ United Kingdom } \\
\hline & Major & Regional & Major & Regional & Major & Regional & Major & Regional \\
\hline Number of orchestras in sample & 9 & 13 & 12 & 8 & 13 & 11 & 7 & 5 \\
\hline Concerts exclusively & 5 & 6 & 4 & 5 & 13 & 11 & 6 & 2 \\
\hline Opera and/or theater & 2 & 7 & 3 & 3 & 0 & 0 & 0 & 0 \\
\hline Broadcast & 2 & 0 & 5 & 0 & 0 & 0 & 1 & 3 \\
\hline Mean orchestra size & 133 & 67 & 121 & 71 & 101 & 79 & 93 & 76 \\
\hline Mean date founded & 1818 & 1867 & 1920 & 1917 & 1904 & 1943 & 1904 & 1931 \\
\hline \multicolumn{9}{|l|}{ Orchestra composition } \\
\hline Mean percent women players & 11 & 23 & 11 & 23 & 25 & 47 & 24 & 39 \\
\hline Mean percent foreign players & 1 & 20 & 21 & 42 & 3 & 1 & 4 & 3 \\
\hline \multicolumn{9}{|l|}{ Player demographics (means) } \\
\hline Age & 42.0 & 40.0 & 41.0 & 37.0 & 44.0 & 35.0 & 37.0 & 38.0 \\
\hline Years in orchestra & 6.9 & 6.1 & 6.0 & 5.6 & 6.1 & 5.1 & 5.2 & 5.3 \\
\hline Years in position & 6.6 & 5.7 & 5.9 & 5.4 & 5.6 & 4.6 & 4.9 & 5.0 \\
\hline Number of previous orchestras & 1.9 & 2.0 & 2.2 & 2.0 & 2.3 & 3.0 & 1.9 & 2.0 \\
\hline
\end{tabular}

country. We then visited each of the 78 orchestras in the sample to conduct interviews, make observations, and obtain archival data (concert programs, rosters of players and managers, financial data, and concert attendance figures) for 1985-1990. Interviewees included orchestra managers, officials of governing boards or agencies, players, and support staff. When possible, we also observed rehearsals and concerts. We summarized and coded archival, interview, and observational data on a recording form designed to maximize the comparability of data across orchestras and countries (for details, see Allmendinger et al., 1993).

Data about the social and regulatory context of East German orchestras were obtained primarily from interviews with officials of the government agency responsible for theaters and orchestras (the Direktion für Theater und Orchester, or DTO) and with the spokesman for the acting East German Minister of Culture, and from the official press organ Theater der Zeit from 1960 through 1989, the occasional publication Decisions and Announcements of the Ministry of Culture, and the East German collective contract for artists. Detailed information about specific orchestras was taken from the annual Ensembles der Deutschen Demokratischen Republik from 1985 to 1990 and from several editions of Information, published by the DTO.

Archival data supplied by East German orchestras presented some special interpretive challenges. Budgets, a managerial staple in Western orchestras, were not used by (or, in some cases, even available to) most East German orchestra managers. Attendance data were of questionable reliability because of political requirements that concert halls be full, and even seemingly straightforward historical data, such as lists of former conductors, could not be taken at face value. Also, because smaller orchestras often exchanged musicians, their official rosters sometimes did not provide complete data about who actually played in them. Despite 
these difficulties, the cooperation of East German players, managers, and public officials was exemplary. No orchestra declined to participate, no one we sought to interview turned us away, and the survey return rate was higher in East Germany than in any other country.

\section{Survey Data}

To tap players' views of their orchestras, we developed and administered a survey to a subset of players of each orchestra. The survey, which consisted of 87 items distributed across six sections, was based on previous research by one of the authors (Hackman, 1990), supplemented by observations and interviews at a subset of orchestras in the present sample. It assessed players' perceptions of the organizational features of their orchestras, within-orchestra interpersonal processes, and the behaviors of orchestra leaders. In addition, the survey asked about each respondent's own work motivation, satisfaction, and career history. Originally drafted in English, the survey was translated into German and partially back-translated by bilingual members of the research team.

The survey was administered to a stratified random sample of 15 players in each orchestra: two first violins, two second violins, one viola, one cello, one bass, two woodwinds, two brass, one percussion, and three principal players (one each from the strings, woodwinds, and brass/percussion). Six orchestras did not participate in the survey portion of the research: two major and two regional orchestras in West Germany and one major and one regional orchestra in the United States. After the first round of surveys had been returned, we sent additional surveys to most orchestras. The same sampling plan was used in the second round, except that women were deliberately oversampled to permit comparative analyses of the responses of male and female players (see Allmendinger and Hackman, 1995).

Surveys were anonymous, although they did identify the respondent's orchestra, section, and status as a principal or tutti player. Total sample size for the main analyses reported in this paper is 72 orchestras and 992 respondents. The number of orchestras, number of respondents, and response rates for each country are as follows: East Germany: 22 orchestras, 357 respondents (59 percent); West Germany: 20 orchestras, 186 respondents (45 percent); United States: 24 orchestras, 290 respondents (52 percent); United Kingdom: 12 orchestras, 159 respondents (51 percent).

We derived sixteen composite measures from the survey items. These were based on the a priori framework used to select and generate items, supplemented by factor analyses of data from 924 respondents and by inspections of item means, standard deviations, and intercorrelations. We retained five single items of special interest, resulting in a total of 21 measures. They are grouped into four domains: (a) organizational features of the orchestra, (b) orchestral process and performance, (c) player motivation and satisfaction, and (d) music director behavior. All measures range from 1 (low) to 7 (high), except for those assessing the behavior of the music director, which range from 1 to 5 . 
Table 2

\begin{tabular}{|c|c|c|c|c|}
\hline \multicolumn{5}{|c|}{ Means and Standard Deviations of Measures* } \\
\hline Measure & Items & Mean & S.D. & Reliability \\
\hline \multicolumn{5}{|l|}{ Organizational features of the orchestra } \\
\hline Integrity as an ensemble & 8 & 5.05 & 1.00 & .73 \\
\hline Orchestra structure: Task and composition & 5 & 4.86 & 1.03 & .65 \\
\hline Player involvement and opportunities & 8 & 4.10 & 1.11 & .76 \\
\hline Adequacy of resources & 2 & 4.20 & 1.81 & .59 \\
\hline \multicolumn{5}{|l|}{ Single items: } \\
\hline Recognition (Excellent playing pays off) & & 5.50 & 1.51 & - \\
\hline Recruitment (Fair and effective) & & 5.28 & 1.60 & - \\
\hline \multicolumn{5}{|l|}{ Orchestral process and performance } \\
\hline Quality of internal processes & 7 & 4.76 & 1.03 & .78 \\
\hline Musical outcomes & 3 & 4.81 & 1.25 & .70 \\
\hline \multicolumn{5}{|l|}{ Single items: } \\
\hline Finances (Getting stronger financially) & & 3.35 & 1.84 & 一 \\
\hline Stability (Organization not falling apart) & & 5.92 & 1.54 & - \\
\hline \multicolumn{5}{|l|}{ Player motivation and satisfaction } \\
\hline General satisfaction & 3 & 5.61 & 1.21 & .74 \\
\hline Internal work motivation & 3 & 6.21 & 0.79 & .69 \\
\hline Job involvement & 1 & 4.70 & 2.04 & - \\
\hline \multicolumn{5}{|l|}{ Satisfaction with: } \\
\hline Compensation & 2 & 3.87 & 1.75 & .73 \\
\hline Job security & 2 & 4.82 & 1.48 & .88 \\
\hline Management & 3 & 4.28 & 1.48 & .86 \\
\hline Work relationships & 3 & 4.93 & 0.98 & .58 \\
\hline Growth opportunities & 4 & 4.84 & 1.17 & .79 \\
\hline \multicolumn{5}{|l|}{ Behavior of the music director } \\
\hline Direction-setting & 5 & 3.67 & 1.09 & .92 \\
\hline Organizational initiatives & 7 & 3.15 & 0.98 & .84 \\
\hline Coaching & 5 & 2.82 & 0.90 & .79 \\
\hline
\end{tabular}

* Based on respondents from all countries. Number of responses ranges from 886 to 924 .

The measures, grouped by domain, are described in the Appendix. Means, standard deviations, and internal consistency reliabilities are reported in Table 2 . We assessed discriminant validities of the measures by comparing the average intercorrelation among items that make up a given composite score with those items in the same section of the survey that do not contribute to that score (off-diagonal correlations). The median within-composite correlation is .46, compared with a median off-diagonal correlation of .24, which is satisfactory. Three measures have relatively weak discriminant validities: integrity as an ensemble, music director organizational initiatives, and music director coaching.

We compared within-composite, off-diagonal, and between-composite correlations for the 21 measures across countries. Patterns of intercorrelations were quite similar across nations, which provides assurance about the comparability of players' responses to the English and German versions of the instrument and permits use of the same composite scores for all countries (Allmendinger et al., 1993).

Finally, we computed intraclass correlations across orchestras for all survey variables for which players described their orchestra and leaders. All of these 
correlations were significant, which allowed us to aggregate the responses of players within orchestras to generate organization-level scores for each of these variables (Kenny and LaVoie, 1985).

\section{Supplementary Data}

We collected survey data from East German players between January and May 1990, which was after the Berlin Wall had been breached but before formal reunification of the two Germanies. Because it was becoming evident that reunification threatened the survival of some orchestras we were studying (Allmendinger, 1990; Allmendinger and Hackman, 1991), we collected three sets of additional data to track empirically what was happening.

First, we sent a semistructured questionnaire to the senior managers of all 76 orchestras in East Germany in June 1991, asking them what had changed and what had remained the same for their orchestras. Twenty-two managers (29 percent) returned completed questionnaires. Second, musicians who had been sent player surveys in 1990 were contacted again in May and June 1991 and asked if they would be willing to (a) retake the same survey and (b) complete a brief supplementary instrument that asked specifically about any recent changes in their orchestras. Of the 90 musicians who returned these materials, there were 65 matched pairs (72 percent) who responded in both 1990 and 1991. With these data we were able to do a comparative analysis of the 1990 and 1991 data using players as their own controls. Finally, we sent the player survey to an additional 300 musicians who had not participated in the 1990 survey, following the same sampling plan that was used for second-round data collection in the other countries. We received usable responses from 158 players (53 percent).

\section{RESULTS I: CONTEXTUAL CHANGES}

The historical and archival data reported in this section address our first research question-namely, the degree to which East German symphony orchestras were buffered from the full impact of the national-level political and economic changes that occurred after World War II and then again in the late 1980s.

\section{The Making of a Socialist Cultural Environment: 1945-1990}

The socialist regime took power in East Germany in 1945. Subsequently, the borders of the country were closed, the state assumed control over virtually all aspects of society, and there was a sharp break from previous political, economic, and cultural policies. The German states (Länder), which had provided the financial support for symphony orchestras, were abolished in 1952. Churches were disenfranchised and no longer provided venues for musical performances. By the mid-1950s, both the financial support and the control of symphony orchestras were firmly in the hands of the central government.

Cultural policy. One tenet of state cultural policy was to bring the German musical tradition to all the people of the 
land (Mehner, 1990). Before the socialist regime came to power, there were 48 orchestras in the geographical area that was to become the East German state. By 1990, East Germany had 76 professional symphony orchestras in a country slightly smaller than the state of Tennessee. There was one symphony orchestra in East Germany for every 220,000 citizens, a higher density than in any other country in the world (Allmendinger and Hackman, 1994).

Not all orchestras were created equal, however. Although state policy explicitly promoted the democratization of culture, its implementation resulted in a few world-class ensembles, designated "Class $A$ " orchestras, scattered among a much larger number of " $\mathrm{B}$ " and " $\mathrm{C}$ " class orchestras. The higher the class, the more fixed positions, the larger the annual budget, and the higher the pay of players. Orchestras could not improve their standing, nor was there any real risk of demotion to a lower class.

The state policy of democratizing culture went far beyond simply creating more orchestras. Many orchestras were required to travel to communities that did not have their own, to perform in schools, and to hold concerts in industrial complexes (Kombinate). Moreover, "cultural brigades" were created as an incentive for cultural participation. Members of these self-composed groups engaged in activities consistent with state ideology, including attending concerts and other cultural events, and were rewarded with salary increases.

State policy oriented orchestras almost exclusively toward East German audiences. Few orchestras were allowed to travel outside the country or to produce recordings for international distribution. The government did, however, make sure that the country's very best orchestras received international exposure, which further elaborated the status hierarchy among orchestras.

The socialist regime closed all but four of the nation's conservatories, which severely limited the supply of orchestra players and kept orchestra size small-a mean of 63 players compared with 76 in West Germany. Highly qualified musicians were in especially short supply because state policy required that conservatories give preference to applicants from working-class backgrounds rather than admit students strictly on the basis of talent. Over time, musician shortages became so serious that orchestras began to import players from other socialist states. Eventually, even the tradition in German orchestras of all-male players was breached, and women were recruited (Allmendinger and Hackman, 1995). Even so, lower-class orchestras often needed to borrow players from one another to cover all the parts of large-ensemble works.

Control of orchestras. Central planners exercised almost complete control over the administration and economics of East German orchestras. Orchestra names, the composition of their audiences, and even the size of their audiences all were centrally determined. Communist party officials were given subscriptions, for example, whether they wanted them or not. And they were counted as attending the concerts to which they had been subscribed, whether they were actually there or not. 
In the early years of the socialist regime, three different state agencies controlled orchestra activities. In 1986, these agencies were merged into the DTO, which assumed responsibility for all aspects of orchestra operations, including artistic policy, personnel matters, and the management of support staff. The centrality of the DTO to the day-to-day operations of orchestras is illustrated by the player selection process. DTO officials auditioned all graduates of the four music schools and assigned each one a technical proficiency score. Orchestras were allowed to consider only musicians whose scores fell within a DTO-specified range. The top-ranked orchestras auditioned and employed the highest-scoring players; lower-ranked orchestras were permitted to consider only players who had received lower scores - if any players at all were available.

Because the wage and price structure of the cultural sector of the economy was artificially stabilized, East German orchestras were protected from international competition and from economic uncertainty. The pay of orchestra musicians, however, was quite low relative to player salaries in other nations. For example, in 1990 a musician in a top-ranked East German orchestra, such as the Berliner Sinfonie Orchester, earned 1,800 marks (roughly \$1200) per month, plus a number of state-supplied goods and services; a typical player in the Berliner Philharmonisches Orchester, a top West German orchestra just across the wall, earned more than four times as much. The wage structure within East German orchestras was flat as well. Whereas principal players in Western orchestras typically earn substantially more than do tutti (section) players, all members of a section were paid nearly the same in East German orchestras.

Orchestras' expense budgets were centrally determined and rarely changed from year to year. Overall budgets were partitioned into funds for specific purposes, and orchestra managers had almost no flexibility in using those funds. An orchestra with money in its instrument fund, for example, rarely could purchase instruments manufactured in East Germany because almost all of them were sold to other nations for hard currency. By contrast, funds for instrument repair were relatively easy to spend, prompting orchestras to repair even instruments that could have been more inexpensively replaced.

The East German policy of "bringing music to the people" was not mere propaganda; the socialist musical culture did result in East German citizens having greater access to serious music. In implementing this policy, the government took control of virtually all decisions that were consequential for orchestras and players. Mid-range government agencies, such as the DTO, did not buffer orchestras from national policies. The opposite happened: With a few exceptions, such as the slow application to orchestras of national policies about women's employment and the relatively greater latitude enjoyed by a few of the country's finest orchestras, these agencies vigorously enforced national cultural policy for all orchestras in the land. The result was high differentiation among the three classes of orchestras, little differentiation and greater interdependence among 


\section{Symphony Orchestras}

orchestras within the lower classes, and a sharp reduction in autonomy and managerial expertise at the orchestra level.

\section{The Disintegration of the Socialist Cultural Context: 1990-1991}

With reunification, much that had been done after the socialist regime took power in 1945 was immediately undone. The border between East and West Germany was abolished, five new federal states were created or reconstituted, churches were re-legitimized, and the Kombinate were closed.

Cultural policy. The Unification Treaty between the two German nations signed in August 1990 required that unification do no damage to the cultural infrastructure or to the cultural traditions of the former East Germany (Article 35, Paragraph 6). Yet the means by which that policy would be implemented-for operas, theaters, and museums as well as for orchestras-was not specified.

Policymakers initially attended almost exclusively to the financial resources needed to ensure the survival of East German cultural institutions. The nation had been spending 246 marks per citizen per year to support culture; by contrast, West Germany was spending only 150 marks per person for culture (estimates from the 1988 Conference of the Ministers of Culture in West Germany). Moreover, financial responsibility for orchestras was differently situated in the two countries: Funds were supplied mainly by state and local agencies in West Germany but by the federal government in East Germany.

These differences between the two countries did not bode well for East German orchestras (Allmendinger, 1990; Zimmer, 1990; Möller, 1991). Not only might central funding be lost, but the precarious finances of the cities and the new states in the former East Germany made it extremely unlikely that they could take up the slack. The Bonn government did establish a transitional plan that provided some federal funds for East German orchestras and gave each player a pay raise of 200 marks per month. In addition, the newly created states were given some funds to support culture, and a few cities were able to provide limited support for their own cultural institutions.

The collective impact of these programs was a modest increase in resources for East German orchestras-and considerable confusion throughout the country about the amount, purposes, and conditions of those resources. The federal transitional funds, for example, were intended merely to help orchestras survive the period of change, during which a number of smaller orchestras were expected to merge. But many East German orchestra players and managers mistakenly viewed the funds as signaling the beginning of a period of relative affluence.

Control of orchestras. By the end of 1990, East German regulatory agencies such as the DTO had ceased to function, and the government no longer had the capability to control the nation's symphony orchestras. Although none were closed (the government did not have the capability to do that either), the new and unfamiliar political-economic context 
posed some significant threats. There were, for example, fewer places for orchestras to perform. The closing of the Kombinate had eliminated one regular venue, many of the community halls where smaller orchestras had performed were no longer available to them, and as Gymnasia deemphasized cultural activities, they stopped inviting orchestras to perform for students. Although corporate sponsors appeared on the East German orchestral scene for the first time ever, they had little immediate impact on either finances or performance opportunities.

Economic realities required that ticket prices be raised, even as people's ability to afford them was dropping. Moreover, public officials no longer were obligated to attend orchestra concerts. The result was audiences that were both smaller (our data show a 30-percent drop in occupied seats between 1985 and 1991) and differently composed than those to which musicians had become accustomed.

As the situation worsened, some top players departed for better-paying orchestras in the West, raising the specter of competition among orchestras for players-something that had not happened since the socialist regime took power in the 1940s. With the borders of the country now open, there was an abundance of new players available to fill vacancies, but orchestras had neither the know-how nor the wherewithal to screen these applicants and select among them.

The societal-level changes that occurred in 1990, like those of the late 1940s, resulted in direct and consequential alterations of the proximal environment of East German orchestras. The previously secure base of resources to support symphonic music vanished, even as the collapse of the DTO dramatically increased orchestras' autonomy over their own affairs. But four decades of central control had been competence-destroying rather than competenceenhancing for East German orchestras (Tushman and Anderson, 1986). Few of them had the expertise needed either to solve the problems or to exploit the opportunities that accompanied the revolutionary events of 1990 .

\section{Conclusion}

The answer to our first research question-about whether mid-range government agencies buffered East German symphony orchestras from the two national-level changes-is clearly negative. In the first instance, high-level decision makers eliminated some entities that had been important features of the orchestral context (such as churches) and created new agencies that became highly salient for orchestras (such as the DTO and the Kombinate). The mid-range government agencies that remained in place, such as municipalities, potentially could have buffered orchestras from the full impact of these changes, but they did not. In the second instance, the collapse of the government rendered financially and administratively impotent the very institutions that had become the most consequential features of the orchestral context under socialism. 


\section{Symphony Orchestras}

The contextual changes were real jolts. They were neither invented by orchestras (Starbuck, 1976: 1069) nor merely enacted by them (Weick, 1993: 372-373). Nor were they gradual adjustments that organizational actors perceived as discontinuous only retrospectively (Lenz and Engledow, 1986: 343-344). That symphony orchestras in East Germany were part of a longstanding and widely valued cultural institution afforded them virtually no protection from the profound changes that took place at the center of the national government.

\section{RESULTS II: ORCHESTRAS AND PLAYERS}

To address our second research question, we turn from contextual analysis to an examination of East German orchestras as organizations. How did orchestra operations and the life and work of orchestra players change in response to the two national-level political-economic changes?

The Impact of the Socialist Context on Orchestras and Players: 1945-1990

Although longitudinal data are not available for East German orchestras for the 1945-1990 period, certain within- and between-country comparisons using 1990 data can be used to assess the impact of the socialist context on orchestras and their members. It was clear in 1990 that significant political changes were on the horizon, but little had actually changed yet. The survey and observational data collected that year therefore provide a reasonable depiction of East German orchestras at the very end of the socialist regime.

Three comparisons inform our research question. The first is within the German cultural tradition: East vs. West German orchestras. The second is between traditions: the two German states vs. the United States and the United Kingdom. And the third is within nation: major vs. regional orchestras. If differences between the two German states (the within-tradition comparison) are more substantial than those between traditions and within nations, that would suggest that the contextual changes instituted by the socialist regime did alter the functioning of orchestras as organizations. If the differences between the two German states are smaller in magnitude than either the between-tradition or the within-nation comparisons, however, that would suggest that the changes in the East German political-economic context had relatively little effect on orchestras and their players.

Cross-national differences were analyzed using the SAS General Linear Models program. We first computed orchestra means using the 1990 survey data. These means were then analyzed in a model that included terms for country, standing (major vs. regional orchestras), country by standing, and specific orchestra nested within standing. Orchestra was treated as a random effect, and the error term for testing the effect of standing was adjusted accordingly.

Findings are shown in Table 3. East vs. West German comparisons, on average, control far less variance than do either (a) comparisons of the two German nations, taken 
Sources of Variation: Orchestra Standing, German-German, and International Comparisons*

\begin{tabular}{|c|c|c|c|}
\hline \multirow[b]{2}{*}{ Measure } & \multicolumn{3}{|c|}{ Percent variance controlled } \\
\hline & $\begin{array}{c}\text { East vs. } \\
\text { West Germany }\end{array}$ & $\begin{array}{c}\text { East + West Germany } \\
\text { vs. USA + UK }\end{array}$ & $\begin{array}{l}\text { Major vs. } \\
\text { regional orchestras }\end{array}$ \\
\hline \multicolumn{4}{|l|}{ Organizational features of the orchestra } \\
\hline Integrity as an ensemble & $0 \%$ & $19 \%$ & $11 \%$ \\
\hline Orchestra structure: Task and composition & $8 \%$ & $0 \%$ & $16 \%$ \\
\hline Player involvement and opportunities & $5 \%$ & $16 \%$ & $8 \%$ \\
\hline Adequacy of resources & $8 \%$ & $0 \%$ & $8 \%$ \\
\hline \multicolumn{4}{|l|}{ Single items: } \\
\hline Recognition (Excellent playing pays off) & $1 \%$ & $19 \%$ & $26 \%$ \\
\hline Recruitment (Fair and effective) & $0 \%$ & $11 \%$ & $5 \%$ \\
\hline \multicolumn{4}{|l|}{ Orchestral process and performance } \\
\hline Quality of internal processes & $6 \%$ & $0 \%$ & $17 \%$ \\
\hline Musical outcomes & $0 \%$ & $13 \%$ & $0 \%$ \\
\hline \multicolumn{4}{|l|}{ Single items: } \\
\hline Finances (Getting stronger financially) & $3 \%$ & $38 \%$ & $0 \%$ \\
\hline Stability (Organization not falling apart) & $0 \%$ & $8 \%$ & $14 \%$ \\
\hline \multicolumn{4}{|l|}{ Player motivation and satisfaction } \\
\hline General satisfaction & $0 \%$ & $33 \%$ & $4 \%$ \\
\hline Internal work motivation & $17 \%$ & $8 \%$ & $0 \%$ \\
\hline Job involvement & $6 \%$ & $61 \%$ & $0 \%$ \\
\hline \multicolumn{4}{|l|}{ Satisfaction with: } \\
\hline Compensation & $27 \%$ & $0 \%$ & $11 \%$ \\
\hline Job security & $5 \%$ & $2 \%$ & $12 \%$ \\
\hline Management & $0 \%$ & $16 \%$ & $2 \%$ \\
\hline Work relationships & $10 \%$ & $4 \%$ & $6 \%$ \\
\hline Growth opportunities & $4 \%$ & $7 \%$ & $4 \%$ \\
\hline
\end{tabular}

* Based on planned contrasts of an analysis involving the main and interactive effects of country, standing (major vs. regional), and orchestra. $N=72$ orchestras.

together, with the United States and United Kingdom or (b) comparisons of major vs. regional orchestras within countries. The East vs. West German comparison controls more than 10 percent of the variance for only two of our 18 measures: internal work motivation and satisfaction with compensation. These findings are confirmed by a profile analysis of the country means for our ten measures of organizational features and orchestral processes. The D-squared index of profile similarity (Nunnally, 1978: 443) for East and West German orchestras is 1.9, compared with an index of 5.6 for the means of East and West German orchestras taken together relative to the means of United States and United Kingdom orchestras taken together (the lower the index, the greater the profile similarity).

The substantive differences between East German orchestras and those in the other three countries in the sample are shown in Table 4. Overall, East German players reported that their orchestras were, under socialism, relatively well structured and stable as organizations, a finding that is generally consistent with our observational and archival data (Allmendinger and Hackman, 1994). Relationships among East German players were more positive than acrimonious, and player motivation, satisfaction, and job involvement were quite high. At the same time, resources were insufficient, players were 


\begin{tabular}{|c|c|c|c|c|c|c|}
\hline \multicolumn{7}{|c|}{ Cross-national Comparison of Measures from the Player Survey* } \\
\hline Measure & $\begin{array}{c}\text { East } \\
\text { Germany }\end{array}$ & $\begin{array}{c}\text { West } \\
\text { Germany }\end{array}$ & $\begin{array}{l}\text { United } \\
\text { States }\end{array}$ & $\begin{array}{l}\text { United } \\
\text { Kingdom }\end{array}$ & F-ratio & $p$ \\
\hline \multicolumn{7}{|l|}{ Organizational features of the orchestra } \\
\hline Integrity as an ensemble & 5.34 & 5.23 & 4.67 & 4.68 & 8.73 & .001 \\
\hline Orchestra structure: Task and composition & 5.03 & 4.60 & 4.74 & 4.75 & 3.28 & .030 \\
\hline Player involvement and opportunities & 4.33 & 4.02 & 3.97 & 3.44 & 7.25 & .001 \\
\hline Adequacy of resources & 3.56 & 4.58 & 4.80 & 3.76 & 5.44 & .003 \\
\hline \multicolumn{7}{|l|}{ Single items: } \\
\hline Recognition (Excellent playing pays off) & 5.68 & 5.77 & 5.04 & 5.07 & 9.35 & .001 \\
\hline Recruitment (Fair and effective) & 5.51 & 5.53 & 5.06 & 4.81 & 3.59 & .020 \\
\hline \multicolumn{7}{|l|}{ Orchestral process and performance } \\
\hline Quality of internal processes & 4.78 & 4.42 & 4.79 & 4.62 & 2.68 & .060 \\
\hline Musical outcomes & 4.61 & 4.50 & 4.96 & 5.26 & 4.17 & .010 \\
\hline \multicolumn{7}{|l|}{ Single items: } \\
\hline Finances (Getting stronger financially) & 2.11 & 2.81 & 4.48 & 4.15 & 19.36 & .001 \\
\hline Stability (Organization not falling apart) & 5.98 & 6.09 & 5.88 & 5.46 & 2.31 & .090 \\
\hline \multicolumn{7}{|l|}{ Player motivation and satisfaction } \\
\hline General satisfaction & 5.87 & 5.80 & 5.38 & 4.83 & 15.70 & .001 \\
\hline Internal work motivation & 6.45 & 6.05 & 6.14 & 5.96 & 9.15 & .001 \\
\hline Job involvement & 6.30 & 5.19 & 3.24 & 3.33 & 139.81 & .001 \\
\hline \multicolumn{7}{|l|}{ Satisfaction with: } \\
\hline Compensation & 3.03 & 4.84 & 4.14 & 3.81 & 19.54 & .001 \\
\hline Job security & 4.15 & 5.03 & 5.14 & 4.77 & 5.44 & .003 \\
\hline Management & 4.36 & 4.45 & 4.24 & 3.51 & 6.39 & .001 \\
\hline Work relationships & 4.95 & 4.68 & 4.95 & 5.00 & 3.26 & .030 \\
\hline Growth opportunities & 5.00 & 4.73 & 4.85 & 4.29 & 5.84 & .002 \\
\hline
\end{tabular}

* Country means are the average of the means of individual orchestras. $N=72$ orchestras.

concerned that their orchestras were slipping musically and financially, and there was pervasive unhappiness with pay and job security.

The political-economic system within which East German orchestras operated from 1945 to 1990 did affect orchestra operations and player motivation and satisfaction. Yet the size of these effects is modest for most measures. Clearly, the musical and organizational traditions of East German orchestras were not destroyed by the 45 years of socialist rule.

Orchestras in West Germany also were changing between 1945 and 1990_-but in the opposite direction, which should have increased the size of obtained differences between the two nations. Although West German orchestras continued to be supported mainly by the Länder and the cities, the national economic context in which they operated became increasingly capitalist and market oriented. Moreover, satisfactory concert halls were available to all West German orchestras, instruments and music libraries were rarely a problem, and there were both funds and opportunities for international tours by many orchestras. Yet these orchestras also did not stray far from the continental tradition of a state-supported musical culture. Overall, our findings suggest that it was more consequential in 1990 to be a German orchestra than it was to be an orchestra in a socialist nation. 


\section{The Impact of Reunification on Orchestras and Their Players: 1990-1991}

To examine how orchestras and players responded to this second major political-economic change, we analyzed data within the East German nation, comparing the 1990 and 1991 responses of those players who completed the research survey both years. We excluded from this analysis four players who were the only ones from their orchestras to respond to both rounds of the survey. Data for the remaining 61 players were analyzed in a general linear model that included terms for standing (major vs. regional), time (1990 vs. 1991), standing by time, orchestra nested within standing, time by orchestra, and individual respondent nested within orchestra. Orchestra and respondent were treated as random effects, and error terms were adjusted accordingly. Because there were unequal numbers of respondents from different orchestras, means were first computed for each orchestra and then averaged to generate overall means for the two years.

As is seen in Table 5, the trend is modestly positive. The 1990 and 1991 means differ significantly for four measures, two of which have to do with money: In 1991, players reported that their orchestras were getting stronger financially and that they were happier than before with their pay. This finding surely reflects hope as well as reality, since the promised transitional funds for orchestras had not yet arrived when the 1991 survey was administered. Apparently, players' anticipation of those funds-coupled with the token pay increase they had received-sufficed to alter their perception of and their satisfaction with orchestra finances.

Players in 1991 also reported that they now had heightened involvement in their organizations and expanded opportunities for influence and mobility. This is consistent with the movement, observed in many orchestras, for players to take the reins of leadership from those state-appointed officials who previously had held them. Finally, players reported that their orchestras had improved musically between 1990 and 1991. Given that attendance for most East German orchestras was dropping sharply in the early months of 1991, this finding is unexpected. Yet the people who now were attending concerts were more overtly appreciative than they had been before-they were, after all, there because they wanted to be rather than because they were expected to be. Given musicians' attentiveness to the reactions of their audiences, this may have been enough to engender a perception that their orchestras were, in fact, improving musically.

\section{Conclusion}

East German orchestras exhibited remarkable stability and continuity with their traditions despite two radical changes in the country's political-economic system. This finding provides additional evidence of the power of institutional processes to foster continuity even under conditions of revolutionary change (Skocpol, 1976). The answer to our second research question, then, is that the two major political-economic changes only modestly affected orchestral functioning and the life and work of players. 


\begin{tabular}{|c|c|c|c|c|}
\hline \multirow[b]{2}{*}{ Measure } & \multicolumn{3}{|c|}{$\begin{array}{l}\text { Main effects } \\
\text { for time }\end{array}$} & \multirow{2}{*}{$\begin{array}{c}\begin{array}{c}\text { Time by } \\
\text { standing interactions }\end{array} \\
\text { F-ratio }\end{array}$} \\
\hline & 1990 & 1991 & F-ratio & \\
\hline \multicolumn{5}{|l|}{ Organizational features of the orchestra } \\
\hline Integrity as an ensemble & 5.28 & 5.30 & 0.03 & $4.40^{\circ}$ \\
\hline Orchestra structure: Task and composition & 5.05 & 4.95 & 0.71 & 0.01 \\
\hline Player involvement and opportunities & 4.33 & 4.50 & $4.08^{\bullet}$ & $10.17^{\bullet \bullet}$ \\
\hline Adequacy of resources & 3.86 & 4.08 & 2.07 & 1.92 \\
\hline \multicolumn{5}{|l|}{ Single items: } \\
\hline Recognition (Excellent playing pays off) & 5.56 & 5.68 & 0.57 & $4.12^{\bullet}$ \\
\hline Recruitment (Fair and effective) & 5.48 & 5.57 & 0.57 & $3.91^{\bullet}$ \\
\hline \multicolumn{5}{|l|}{ Orchestral process and performance } \\
\hline Quality of internal processes & 4.68 & 4.77 & 0.96 & 0.92 \\
\hline Musical outcomes & 4.29 & 4.59 & $5.76^{\bullet}$ & 1.89 \\
\hline \multicolumn{5}{|l|}{ Single items: } \\
\hline Finances (Getting stronger financially) & 2.25 & 3.29 & $21.37^{\bullet \bullet}$ & 0.15 \\
\hline Stability (Organization not falling apart) & 5.87 & 5.80 & 0.16 & 0.01 \\
\hline \multicolumn{5}{|l|}{ Player motivation and satisfaction } \\
\hline General satisfaction & 5.72 & 5.84 & 1.58 & 0.61 \\
\hline Internal work motivation & 6.38 & 6.22 & 3.40 & 0.05 \\
\hline Job involvement & 6.10 & 6.11 & 0.02 & 1.43 \\
\hline \multicolumn{5}{|l|}{ Satisfaction with: } \\
\hline Compensation & 2.88 & 3.56 & $13.91^{\bullet \bullet}$ & 0.16 \\
\hline Job security & 4.25 & 4.57 & 1.69 & 1.56 \\
\hline Management & 4.26 & 4.54 & 2.05 & 0.46 \\
\hline Work relationships & 4.93 & 4.87 & 0.36 & 0.53 \\
\hline Growth opportunities & 4.91 & 4.96 & 0.05 & 0.17 \\
\hline
\end{tabular}

$\bullet p<.05 ; \bullet p<.01$.

* The 1990 and 1991 means are the averages of the means of individual orchestras. $N=61$ players, each at two points in time. Means for significant interactions between time (1990 vs. 1991) and orchestra standing (major vs. regional) are presented in Figure 1.

The homogeneity that was observed during the socialist period was overdetermined. Beyond institutional forces, the pervasive administrative and economic control of orchestras made it virtually impossible for any but a very few international "showcase" ensembles to chart their own futures or to differentiate themselves from others in their state-specified class. When the socialist regime and its regulatory agencies collapsed in 1990, orchestras' latitude to manage themselves increased dramatically, even as their financial security disappeared. Our data show a modest overall improvement in orchestra functioning during this period (Table 5). But we also found that some orchestras were adapting much more successfully to their new opportunities and challenges than were others. We turn next to analysis of the reasons why.

\section{RESULTS III: ADAPTATION PROCESSES}

We address our third research question by drawing on survey, interview, and observational data to identify the factors that distinguish those East German orchestras that fared relatively well under reunification from those whose survival became increasingly uncertain. Our field observations pointed to two factors, one structural and one behavioral, as likely moderators of orchestras' post-reunification well-being: (a) an orchestra's prior standing 
as a major vs. regional ensemble and (b) the number and kinds of leadership initiatives taken by orchestra leaders and players. We examine these two moderators separately and then show how their joint effects set in motion, for some orchestras, self-fueling spirals of increasing (or decreasing) viability.

\section{Orchestra Standing}

The political-economic events of 1990-1991 had quite different consequences for major and regional orchestras. As is seen in Figure 1 and Table 5, all statistically reliable interactions between time and standing have to do with the orchestras' organizational features, and four of the five carry the same message: that higher-standing orchestras were getting stronger and lower-standing orchestras were getting weaker as the events of reunification unfolded. This pattern is found for integrity as an ensemble, for player involvement and opportunities, for performance-contingent recognition, and for fair and effective recruitment processes. It is noteworthy that the measures for which the gap between major and regional orchestras widened are those for which, in 1990, East German means were relatively high (Table 4). This suggests that reunification of the German state risked

Figure 1. Significant time by standing (major vs. regional) interactions: East German orchestras.
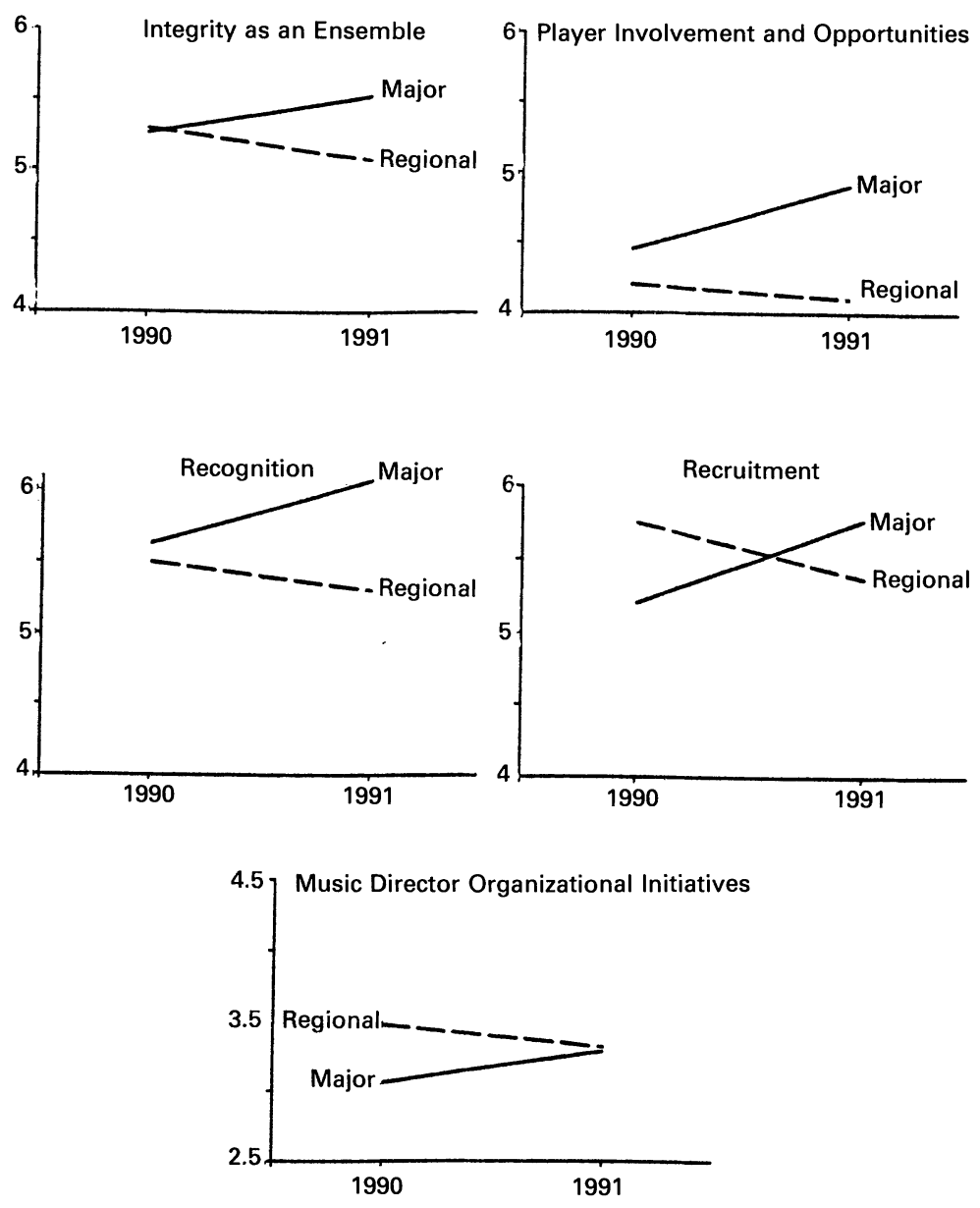


\section{Symphony Orchestras}

compromising some of the special strengths of the many smaller orchestras that had been dispersed so densely throughout the nation.

\section{Leader Initiatives}

We measured three aspects of music director behavior: direction-setting, taking organizational initiatives, and coaching (see the Appendix for the specific behaviors assessed). The significant time-by-standing interaction found for music director organizational initiatives exhibits a pattern complementary to that of the other significant interactions shown in Figure 1. In 1990, the music directors of regional orchestras were taking more initiatives to improve the structure and functioning of their orchestras than were their counterparts in major orchestras. A year later, however, those differences had disappeared. Conductors of regional orchestras were giving less attention to organizational matters than they had before, and those of major orchestras were making more organizational changes than previously, a pattern consistent both with the widening gap between major and regional orchestras on other measures and with our on-site observations.

To further analyze how leader behavior moderated the impact of reunification, we calculated the difference in the level of organizational initiatives taken by music directors between 1990 and 1991, using data from players who described their leaders both years, and then correlated that difference with our dependent measures. Results are shown in Table 6.

Table 6

\section{Correlations between Change in Music Director Organizational Initiatives and Orchestra- and Player-level Measures*}

\begin{tabular}{|c|c|c|}
\hline Measure & Player-level data $(N=65)$ & Orchestra-level data $(N=20)$ \\
\hline \multicolumn{3}{|l|}{ Organizational features of the orchestra } \\
\hline Integrity as an ensemble & $.24^{\bullet}$ & .11 \\
\hline Orchestra structure: Task and composition & .20 & .12 \\
\hline Player involvement and opportunities & $.29^{\bullet \bullet}$ & $.66^{\bullet \bullet \bullet}$ \\
\hline Adequacy of resources & -.04 & -.16 \\
\hline \multicolumn{3}{|l|}{ Single items: } \\
\hline Recognition (Excellent playing pays off) & .20 & .34 \\
\hline Recruitment (Fair and effective) & $.26^{\bullet \bullet}$ & .30 \\
\hline Sections (Are a key organizational feature) & $-.24^{\bullet}$ & -.16 \\
\hline Orchestral processes and outcomes & \multicolumn{2}{|c|}{ (no significant correlations) } \\
\hline \multicolumn{3}{|l|}{ Player motivation and satisfaction } \\
\hline General satisfaction & $.28^{\bullet \bullet}$ & .23 \\
\hline Internal work motivation & .08 & .09 \\
\hline Job involvement & .08 & .11 \\
\hline \multicolumn{3}{|l|}{ Satisfaction with: } \\
\hline Compensation & .12 & $.45^{\bullet \bullet}$ \\
\hline Job security & .20 & .23 \\
\hline Management & $.44^{\bullet \bullet \bullet}$ & $.66^{\bullet \bullet \bullet}$ \\
\hline Work relationships & $.27^{\bullet \bullet}$ & $.43^{\bullet}$ \\
\hline Growth opportunities & $.31^{\bullet \bullet}$ & $.42^{\bullet}$ \\
\hline
\end{tabular}

$\bullet p<.10 ;{ }^{\bullet \bullet} p<.05 ;{ }^{\bullet \bullet} p<.01$.

* Player-level correlations were computed using data from the 65 players who completed surveys both in 1990 and 1991; orchestra-level correlations were computed using average player scores for each of the 20 orchestras for which data were available both years. 
Increased organizational initiatives by music directors were associated with improvements in several organizational features: greater player involvement and opportunities, improved recruitment processes, and greater integrity of the orchestra as a musical ensemble. Change in conductor initiatives was negatively associated with the centrality of sections to the orchestra's work (a measure not discussed elsewhere in this report), suggesting that conductors' actions focused on consolidation of the orchestra as a whole. Significant effects also were obtained for player satisfaction with management, with work relationships, and with growth opportunities. These are precisely the kinds of affective changes that one would expect to find in an orchestra in which the music director had expanded players' opportunities, improved recruitment processes, and strengthened the orchestra as an ensemble-as the music directors of these orchestras had done.

The measures that did not covary with music director organizational initiatives also are informative: orchestra task and composition, adequacy of resources, work motivation and involvement, and all four indicators of orchestral processes and performance. The data reported in Table 6, although correlational and therefore open to alternative interpretations, do suggest that when conductors responded to the events of reunification by focussing their energies on aspects of the organization over which they had direct and immediate control, players subsequently expressed greater satisfaction about those same matters-but not about others.

\section{Change of Leadership}

Six of the 21 orchestras in our sample changed music directors between 1990 and 1991, and seven of them changed technical directors. How did these orchestras fare relative to those whose former leaders remained in place? As shown in Table 7, orchestras that changed music directors scored significantly lower on three indicators of financial and organizational well-being than did orchestras that did not change conductors; orchestras that changed technical directors scored lower on almost all of the measures having to do with organizational design.

It is tempting to conclude from these findings that replacing leaders during a period of radical environmental change invites disaster-an interpretation that would fit well with the population ecology perspective on organizational change (Hannan and Freeman, 1984). In this case, however, the opposite conclusion is more tenable. Our observational data show that orchestras in which leadership changes were made (often at the initiative of players, who hoped that new leaders would make things better) were those that had been in especially poor shape as organizations prior to reunification. Although it no doubt is true that leader behavior makes more of a difference during major organizational reorientations than during periods of stability (Tushman and Romanelli, 1985), the improvements East German players hoped for, if ever they were to come, were not yet evident when we collected follow-up data on their orchestras in 1991. 
Table 7

\begin{tabular}{|c|c|c|c|}
\hline \multicolumn{4}{|c|}{$\begin{array}{l}\text { Comparison of Orchestras That Did and Did Not Change Leaders } \\
\text { between } 1990 \text { and } 1991\end{array}$} \\
\hline Measure & Yes & No & $t$ \\
\hline \multicolumn{4}{|c|}{ Music director replaced } \\
\hline Adequacy of resources & 2.86 & 4.12 & $-2.29^{\bullet \bullet}$ \\
\hline Stability (Organization not falling apart) & 5.23 & 6.31 & $-2.74^{\bullet \bullet \bullet}$ \\
\hline Satisfaction with job security & 3.58 & 4.80 & $-2.29^{\bullet \bullet}$ \\
\hline$N$ & 6 & 15 & \\
\hline \multicolumn{4}{|c|}{ Technical director replaced } \\
\hline Integrity as an ensemble & 5.20 & 5.59 & $-1.75^{\bullet}$ \\
\hline Adequacy of resources & 2.96 & 4.05 & $-2.07^{\bullet \bullet}$ \\
\hline Recognition (Excellent playing pays off) & 5.62 & 6.16 & $-2.62^{\bullet \bullet}$ \\
\hline Recruitment (Fair and effective) & 5.13 & 5.82 & $-2.32^{\bullet \bullet}$ \\
\hline Sections (Are a key organizational feature) & 4.47 & 5.40 & $-2.15^{\bullet \bullet}$ \\
\hline Quality of internal processes & 4.59 & 5.08 & $-2.15^{\bullet \bullet}$ \\
\hline$N$ & 7 & 14 & \\
\hline
\end{tabular}

\section{Player Initiatives}

To further explore the role of players in shaping the post-reunification prospects of East German orchestras, we turned to our observational data to identify eight orchestras in which players took significant leadership initiatives between 1990 and 1991. As shown in Table 8, those eight orchestras were significantly lower on many of our measures than were the thirteen orchestras in which players did not take organizational initiatives. This finding adds credence to the interpretation that players more often take action in orchestras with serious problems than in those that are in relatively good shape. And it is organizational difficulties that are especially likely to incite players: Orchestras in which players took leadership initiatives scored significantly lower on six of our seven measures of organizational features, but on only three of the twelve measures in other domains.

That the consequences of players taking control of their orchestras varied from orchestra to orchestra is illustrated by the following two cases. In a middle-size ensemble near a large city, players fired their music director just as soon as the collapsing political system made it possible to do so. As a replacement, they chose a very young conductor experienced in the ways of Western orchestras. They gave him a short-term contract, keeping other candidates on hold, so they could assess his performance before confirming the appointment-which, after a year and a half, they did. At this writing, the new music director is firmly in control and the orchestra is prospering.

Players in another orchestra, located in a small community near a resort area, were less successful. With the cooperation of the town mayor, who wanted a fine orchestra that would draw tourists and thereby help the local economy, they fired both the music director and the technical director. A famous conductor from another country 


\begin{tabular}{|c|c|c|c|}
\hline \multicolumn{4}{|c|}{ Comparison of Orchestras in Which Players Did and Did Not Take Leadership Initiatives } \\
\hline \multirow[b]{2}{*}{ Measure } & \multicolumn{2}{|c|}{ Player leadership initiatives } & \multirow[b]{2}{*}{$t$} \\
\hline & Yes $(N=8)$ & No $(N=13)$ & \\
\hline \multicolumn{4}{|l|}{ Organizational features of the orchestra } \\
\hline Integrity as an ensemble & 5.14 & 5.59 & $-2.15^{\bullet \bullet}$ \\
\hline Orchestra structure: Task and composition & 4.55 & 5.22 & $-2.55^{\bullet \bullet}$ \\
\hline Player involvement and opportunities & 4.21 & 4.70 & $-2.77^{\bullet \bullet}$ \\
\hline Adequacy of resources & 2.95 & 4.16 & $-2.30^{\bullet \bullet}$ \\
\hline \multicolumn{4}{|l|}{ Single items: } \\
\hline Recognition (Excellent playing pays off) & 5.77 & 6.08 & -1.36 \\
\hline Recruitment (Fair and effective) & 5.24 & 5.76 & $-1.76^{\bullet}$ \\
\hline Sections (Are a key organizational feature) & 4.43 & 5.41 & $-2.42^{\bullet \bullet}$ \\
\hline \multicolumn{4}{|l|}{ Orchestral processes and outcomes } \\
\hline Quality of internal processes & 4.49 & 5.10 & $-2.51^{\bullet \bullet}$ \\
\hline Musical outcomes & 4.86 & 4.73 & 0.36 \\
\hline \multicolumn{4}{|l|}{ Single items: } \\
\hline Finances (Getting stronger financially) & 2.99 & 2.95 & 0.09 \\
\hline Stability (Organization not falling apart) & 5.25 & 6.38 & $-2.45^{\bullet \bullet}$ \\
\hline \multicolumn{4}{|l|}{ Respondent motivation and satisfaction } \\
\hline General satisfaction & 5.68 & 6.07 & -0.92 \\
\hline Internal work motivation & 6.37 & 6.37 & -0.02 \\
\hline Job involvement & 6.15 & 6.08 & 0.41 \\
\hline \multicolumn{4}{|l|}{ Satisfaction with: } \\
\hline Compensation & 3.46 & 3.71 & -0.55 \\
\hline Job security & 3.67 & 4.85 & $-2.30^{\bullet \bullet}$ \\
\hline Management & 4.22 & 4.78 & -1.30 \\
\hline Work relationships & 4.88 & 4.88 & 0.01 \\
\hline Growth opportunities & 4.66 & 5.02 & -0.97 \\
\hline
\end{tabular}

was hired who, together with the new technical director, decided to radically reduce the orchestra's size. That decision was poorly received by players and the already-shaky situation of the orchestra deteriorated even further. Perhaps the new leaders' decisions will turn out to promote the long-term best interest of the community, the orchestra, and the players. The short-term consequences, however, were described by players-whose actions had set the change process in motion-as decidedly negative.

\section{Conclusion}

Our findings point to a significant difference in the ability of major and regional orchestras to adapt to the challenges and opportunities posed by reunification. Major orchestras, which were already relatively strong and well financed, became even more so, giving them influence and opportunities that in other countries are accorded only to a few "star" orchestras. Regional orchestras continued to exist, but they risked losing their special prestige as the orchestras of the people, along with many of the material resources they needed to accomplish their musical work.

Orchestra leadership also clearly moderated the impact of reunification on East German orchestras, in two contrasting ways. On the one hand, leadership initiatives by music directors that addressed organizational features of orchestras were associated with favorable player reports about both orchestra properties and their own satisfaction. These 
findings, although correlational, support the proposition that competent leadership can significantly help organizations adapt to exogenous shocks. On the other hand, leadership initiatives by players - which often included replacement of existing leaders with others of their own choosing-occurred mainly in orchestras that already were troubled-and such initiatives were by no means certain to improve either orchestra health or player well-being.

How are these two findings to be reconciled? We hypothesize that the degree to which leadership initiatives are helpful to an organization in responding to an environmental shock depends on the prior health of the organization as a social system. When a shock hits an organization that is already strong, members are unlikely either to replace their leaders or to take significant leadership initiatives themselves. In this case, competent leadership (indexed here as increased organizational initiatives by existing leaders) is likely to aid adaptation to the exogenous event (Table 6). The situation is reversed, however, when a shock hits an organization that already is dysfunctional. Members of such organizations are more likely to replace existing leaders and/or to take over the leadership of the enterprise than are members of stronger organizations (Tables 7 and 8). But if the organization's troubles are serious, members' initiatives are unlikely to accomplish the needed repairs and, perversely, may even make things worse. This state of affairs, which is akin to what is seen in the United States when employees convert an already-failing business into a worker cooperative, characterizes the experience of several small and struggling East German orchestras during the reunification years.

Taken together, our findings about the moderating effects of orchestra standing and organizational leadership suggest that as the economic context of East German orchestras becomes even more market-oriented, self-fueling performance spirals (Lindsley, Brass, and Thomas, 1995) may further widen the existing gap between major and regional orchestras in that country. Only major orchestras, for example, appear to have material resources and network contacts sufficient to engage technical directors and music directors of the quality needed to see them through what is certain to be a highly turbulent transition period. As McCann and Selsky (1984: 465-466) noted, hyperturbulence can result in a kind of social triage that separates organizations that have adequate adaptive capacity from those that do not. The eventual outcome could be a repartitioning of the population of orchestras in the former East Germany, from the three classes of orchestras created by the socialist government into two groups: strong orchestras occupying what McCann and Selsky call "social enclaves" that preserve their adaptive capacities and weaker orchestras caught in downward-spiraling "social vortices" of suboptimal functioning.

\section{DISCUSSION AND CONCLUSION}

Two conceptual dimensions are helpful in accounting for the differential impact of the 1945 and the 1991 political-economic changes on East German orchestras and 
players: (1) the effect of the changes on resource contingencies (the degree to which the resources available to organizations depend on their actions) and (2) the impact of the changes on organizations' operational autonomy (the amount of latitude organizations have to manage their own affairs).

\section{The Advent of State Socialism}

The first change, to state socialism, simultaneously reduced both resource contingency and operational autonomy. Prior to 1945 , orchestras could negotiate with government agents about resources and, through their actions, potentially improve their standing. This was no longer possible under socialism. All orchestras within each of the three hierarchical classes received roughly equivalent financial, material, and human resources. There was nothing an orchestra could do to improve its situation, nor was there any real risk that its situation would worsen.

Orchestras' operational autonomy also decreased sharply under socialism. State agencies, rather than orchestras, now controlled most personnel matters, how financial resources were to be used, where orchestras were to perform and for whom, and more. The reduction of orchestras' autonomy provided stability and predictability. But it also blurred the boundaries among smaller and poorer orchestras as they struggled together to accomplish their centrally assigned tasks with fewer resources than were actually needed to do so, fostering among them the kinds of linkages that can mitigate the impact of exogenous changes (Miner, Amburgey, and Stearns, 1990).

The simultaneous reduction of resource contingency and operational autonomy under socialism significantly strengthened institutional forces for East German orchestras. Consistent with the predictions of DiMaggio and Powell (1983: 155), they became homogeneous within class as their transactions with state agencies became more extensive and consequential and as the number of visible alternative models decreased. Moreover, as both the need and opportunity for orchestras to take entrepreneurial initiatives declined, the historical and cultural traditions that orchestras shared with each other became increasingly salient.

The power of these institutional forces is illustrated by what happened to the repertoire played by East German orchestras under state socialism. The official policy of the state concert and theater agency was that orchestras would emphasize in their programs music by contemporary composers from socialist countries. Although most people we interviewed assured us that this policy had been implemented, the data say otherwise. We selected one concert program from each orchestra in our sample (excluding special or festival programs and concerts led by guest conductors) and recorded the birthdates of the composers whose works were played. Only 8 percent of the works performed by East German orchestras were by composers born in the twentieth century, compared with 20 percent for West Germany, 24 percent for the United Kingdom, and 32 percent for the United States. Also informative are 


\section{Symphony Orchestras}

the median birthdates of the composers of the works performed. For East Germany, the median composer birthdate was 1809, compared with 1857 for West Germany, 1862 for the United States, and 1864 for the United Kingdom.

Far from being on the cutting edge of contemporary music, then, East German orchestras appear to have exhibited in their music an especially deep commitment to the classical repertoire that was central to their musical heritage. This finding exemplifies Carroll, Delacroix, and Goodstein's (1988) proposition that politically imposed cultural systems often generate behavior opposite to that which is sought. Cultural isomorphism still operates in such circumstances, but "in the sense that the state culture serves as a negative template for the observable organizational culture" (p. 373).

\section{The Fall of the Socialist Regime}

The second major political-economic change brought a nearly complete reversal of the state of affairs just described. The availability of resources became increasingly contingent on orchestras' actions, and as central government agencies stopped functioning, orchestras experienced a sudden and dramatic increase in their operational autonomy. Once again, orchestras had the right and the obligation to handle such matters as personnel decisions, budgets, concert venues, and audience relations.

Although these changes generated uncertainty and threat for East German orchestras, they also invited adaptive responses. Success was by no means assured, however, because both a proactive orientation and management skill were required, and these were qualities that had atrophied for many orchestras during their four decades under state socialism. Our findings show that major orchestras were far better positioned than regional orchestras to take advantage of the situation in 1991. Both the staffing of major orchestras and their recent histories contributed to their ability to respond competently to the threats and the opportunities that accompanied reunification. The structure of these orchestras more closely approximated the international standard, and their managers generally were better qualified and more knowledgeable than those of regional orchestras. Moreover, the top orchestras in East Germany had toured internationally and produced commercial recordings, activities that increased their knowledge of the orchestral world outside their own country. When the time came to take action, therefore, these orchestras were more disposed to act, and they had a greater capability to do so competently.

\section{The Acuity of Conceptual Lenses}

Our findings suggest that different conceptual paradigms are differentially useful for examining organization-environment relations, depending on the nature of the environmental changes that are occurring (Tolbert, 1985: 11-12; Singh, House, and Tucker, 1986; Hambrick and Finkelstein, 1987; Gersick, 1991: 12; Meyer, Goes, and Brooks, 1993). On one hand, when environmental changes decrease both the degree to which resources are contingent on organizational 
actions and organizations' level of operational autonomy, as happened to East German orchestras after the socialist regime took power, then organizations have neither the need nor the capability to take action to improve their situations. Under these conditions, institutional models are particularly useful in tracking what happens within and among organizations. Consistent with the tenets of institutional theory, we saw in our data both increased homogeneity and reinforcement of orchestral heritage and traditions among East German orchestras under socialist rule.

When, on the other hand, environmental changes increase both resource contingencies and operational autonomy, then adaptation models provide especially useful analytic lenses. In our data, such models apply in the period after the fall of state socialism, when there was both need for action (because resources became increasingly contingent on what orchestras did and did not do) and the opportunity to take it (because external agencies no longer dictated to orchestras or constrained their choices).

Some orchestras responded to the threat posed by reunification with inaction or even retrenchment; others exhibited proactive and innovative responses. Our data show that the more proactive strategy, when done with competence, sharply differentiated those orchestras that prospered in the new context from those whose survival began to come into question. It is noteworthy that the actions taken by the most successful orchestras were oriented simultaneously internally, toward increased efficiency and better alignment with the new contextual realities, as would be predicted by rational adaptation models, and externally, in securing funding and new performance venues, as would be predicted by the resource dependency paradigm.

The two historical periods represented by our data fill the diagonal cells of a $2 \times 2$ matrix defined by resource contingency and operational autonomy, as depicted in Figure 2. East German orchestras were low on both dimensions during state socialism and became high on both as the reunification process began to unfold. We can speculate, as well, on the two off-diagonal cells, even though our data do not provide information on them. Consider, first, a situation in which environmental changes result in high resource contingency but low operational autonomy. In such circumstances, organizations are at risk because of high resource contingency, but there is little that leaders and members can do about it because of low operational autonomy. Ecological models, which are pessimistic about the efficacy of actions by organizational representatives, are especially useful in analyzing what happens in this cell of the matrix.

Finally, when changes result in low resource contingency but high operational autonomy, conceptual paradigms that address organization-environment relations may be mostly irrelevant to organizational analysis. Organizational leaders 
Figure 2. The applicability of organization-environment models for analyzing different types of environmental changes.

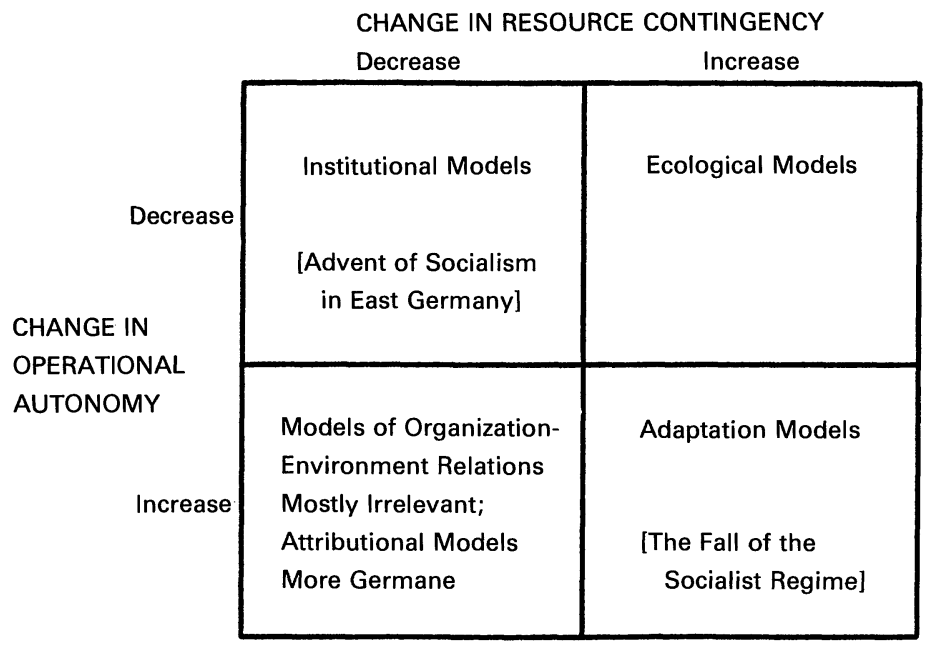

and members can do pretty much whatever they wish, and neither positive nor negative consequences will return from their environments. If resources become increasingly munificent, the organization may perform quite well; if they become increasingly scarce, it may do poorly.

Models of attributional processes may be more germane to such situations than theories of organization-environment relations. In both of the cases just described, for example, members may erroneously attribute the outcomes they obtain to the actions they have taken (March, 1981; Singh, House, and Tucker, 1986). Such attributional errors can be dangerous. An organization that is inefficient and overstaffed, for example, may remain that way (or even grow larger and more cumbersome) if decision makers erroneously conclude that it is their actions that have generated the positive outcomes that are returning from the munificent but noncontingent environment. Similarly, leaders of an organization that is doing poorly in a noncontingent but resource-poor environment may initiate organizational changes that accomplish nothing other than to create additional threat and uncertainty within the enterprise.

The entries in the matrix in Figure 2 summarize our overall findings about the times and circumstances under which institutional dynamics, ecological processes, and organizational adaptation dominate responses to significant societal-level change. Taken as a whole, the findings fit well with the punctuated equilibrium view of system change processes (Miller and Friesen, 1984: chap. 8; Astley, 1985; Tushman and Romanelli, 1985; Gersick, 1991). These theorists follow the lead of contemporary evolutionary biology in viewing organizations as generally being in a state of quasi-stationary equilibrium that occasionally is punctuated by periods of rapid, fundamental, and multidimensional change (Gould, 1980: chap. 17; 1989). Only when the deep structures of a system become dismantled, it is argued, is fundamental change likely to occur (Gersick, 1991). 
The political-economic changes that accompanied the advent of socialism in East Germany in 1945 were, without question, highly significant for people and for institutions throughout the country. But they did not call into question the centuries-old institutional foundation of German symphony orchestras. Our findings suggest the opposite: The simultaneous reduction of both resource contingency and operational autonomy brought by socialism actually strengthened institutional forces. When the socialist regime fell in 1990, however, deep structures were called into question. The institutional structures and systems to which orchestra leaders and members had become well accustomed over the previous four decades no longer operated predictably or, in some cases, no longer operated at all. Possibilities for significant organizational change opened even as orchestra leaders and members throughout the country struggled to make sense of and to begin to respond to the radical new environment in which they suddenly found themselves.

No single model of organization-environment change can adequately explain the experiences of East German orchestras during the two periods of political-economic upheaval they encountered during the last half of this century. The circumstances under which constructive organizational adaptation is even possible are very different from those that condition the success of adaptive activities. Our findings suggest that the possibility of constructive adaptation depends directly on the degree to which environmental changes strengthen resource contingencies and expand organizations' operational autonomy. Even then, only those organizations that are already relatively strong and able to bring competent leadership to bear on their new problems and opportunities have a realistic possibility of adapting successfully to the exogenous changes.

\section{REFERENCES}

Aldrich, Howard E.

1979 Organizations and Environments. Englewood Cliffs, NJ: Prentice-Hall.

Allmendinger, Jutta

1990 "Die Kunst des Überlebens order das Überleben der Kunst?" Frankfurter Rundschau, Nr. 299 (December 24), S. 26.

Allmendinger, Jutta, and J. Richard Hackman

1991 The Survival of Art or the Art of Survival? Report No. 1, Cross-National Study of Symphony Orchestras, Harvard University.

1994 Bringing Music to the People: Continuity and Discontinuity in East German Orchestras. Report No. 3 (rev.), Cross-National Study of Symphony Orchestras, Harvard University.
1995 "The more, the better? A four-nation study of the inclusion of women in symphony orchestras." Social Forces, 74: 423-460.

Allmendinger, Jutta, J. Richard Hackman, Larissa Kowal-Wolk, and Erin V. Lehman

1993 Methods and Measures for the Cross-National Study of Symphony Orchestras. Report No. 4, Cross-National Study of Symphony Orchestras, Harvard University.

$\rightarrow$ Astley, W. Graham

1985 "The two ecologies: Population and community perspectives on organizational evolution." Administrative Science Quarterly, 30: 224-241.
Astley, W. Graham, and Andrew H. Van de Ven

1983 "Central perspectives and debates in organization theory." Administrative Science Quarterly, 28: 245-273.

Barnard, Chester I.

1938 The Functions of the Executive. Cambridge, MA: Harvard University Press.

Becker, Heinz

1962 "Orchester." In Allgemeine Enzyklopädie der Musik (Bd. 10): 168-196. Kassel: Bärenreiter-Verlag.

Blau, Judith R.

1988 "Study of the arts." In Annual Review of Sociology, 14: 269-292. Palo Alto, CA: Annual Reviews.

1989 The Shape of Culture. Cambridge: Cambridge University Press. 


\section{Symphony Orchestras}

Carroll, Glenn R., Jacques

Delacroix, and Jerry Goodstein

1988 "The political environments of organizations: An ecological view." In Larry L. Cummings and Barry M. Staw (eds.), Research in Organizational Behavior, 10: 359-392.

Greenwich, CT: JAI Press.

Child, John

1972 "Organizational structure, environment and performance: The role of strategic choice." Sociology, 6: 2-22.

$\rightarrow$ DiMaggio, Paul J., and Walter W. Powell

1983 "The iron cage revisited: Institutional isomorphism and collective rationality in organizational fields." American Sociological Review, 48: 147-160.

DiMaggio, Paul, and Michael Useem

1983 "Cultural democracy in a period of cultural expansion: The social composition of arts audiences in the United States." In Jack B. Kamerman and Rosanne Martorella (eds.), Performers and Performances: The Social Organization of Artistic Work: 199-225. New York: Praeger.

Gersick, Connie J. G.

1991 "Revolutionary change theories: A multi-level exploration of the punctuated equilibrium paradigm." Academy of Management Review, 16: 10-36.

1994 "Pacing strategic change: The case of a new venture." Academy of Management Journal, 37: 9-45.

Goldfarb, Jeffrey C.

1980 The Persistence of Freedom: The Sociological Implications of Polish Student Theater. Boulder, CO: Westview Press.

Gould, Stephen J.

1980 The Panda's Thumb. New York: Norton.

1989 "Punctuated equilibrium in fact and theory." Journal of Social Biological Structure, 12: 117-136.

Hackman, J. Richard (ed.)

1990 Groups That Work (And Those That Don't). San Francisco: Jossey-Bass.
Hambrick, Donald C., and Sydney

Finkelstein

1987 "Managerial discretion: A bridge between polar views of organizational outcomes." In Larry L. Cummings and Barry M. Staw (eds.), Research in Organizational Behavior, 9: 369-406. Greenwich, CT: JAI Press.

$\rightarrow$ Hannan, Michael T., and John Freeman

1977 "The population ecology of organizations." American Journal of Sociology, 82: 929-964.

1984 "Structural inertia and organizational change." American Sociological Review, 49: 149-164.

1989 Organizational Ecology. Cambridge, MA: Harvard University Press.

$\rightarrow$ Haveman, Heather A.

1992 "Between a rock and a hard place: Organizational change and performance under conditions of fundamental environmental transformation."

Administrative Science Quarterly, 37: 48-75.

Kenny, David A., and Lawrence LaVoie

1985 "Separating individual and group effects." Journal of Personality and Social Psychology, 48: 339-348.

Lawrence, Paul R., and Jay W.

Lorsch

1967 Organization and Environment. Boston: Harvard Graduate School of Business Administration.

$\rightarrow$ Lenz, R. T., and Jack L. Engledow 1986 "Environmental analysis: The applicability of current theory." Strategic Management Journal, 7: 329-346.

$\rightarrow$ Lindsley, Dana H., Daniel J. Brass, and James B. Thomas

1995 "Efficacy-performance spirals: A multilevel perspective." Academy of Management Review, 20: 645-678.

$\rightarrow$ March, James G.

1981 "Footnotes to organizational change." Administrative Science Quarterly, 26: 563-577.
Martorella, Rosanne

1983 "Art and public policy: Ideologies for aesthetic welfare." In Jack B. Kamerman and Rosanne Martorella (eds.), Performers and Performances: The Social Organization of Artistic Work: 281-288. New York: Praeger.

$\rightarrow$ McCann, Joseph E., and John Selsky

1984 "Hyperturbulence and the emergence of type 5 environments." Academy of Management Review, 9: 460-470.

Mehner, Klaus

1990 "Zwischen Neubeginn und Tradition." Musik und Gesellschaft, 40: 247-252.

$\rightarrow$ Meyer, Alan D.

1982 "Adapting to environmental jolts." Administrative Science Quarterly, 27: 515-537.

Meyer, Alan D., James B. Goes, and Geoffrey R. Brooks

1993 "Organizations reacting to hyperturbulence." In George P. Huber and William $\mathrm{H}$. Glick (eds.). Organizational Change and Redesign: 66-111. New York: Oxford University Press.

Meyer, John W., and Brian Rowan 1977 "Institutionalized organizations: Formal structure as myth and ceremony." American Journal of Sociology, 83: 340-363.

Miller, Danny, and Peter $\mathrm{H}$.

Friesen

1984 Organizations: A Quantum View. Englewood Cliffs, NJ: Prentice-Hall.

Miner, Anne S., Terry L.

Amburgey, and Timothy $M$. Stearns

1990 "Interorganizational linkages and population dynamics: Buffering and transformational shields." Administrative Science Quarterly, 35: 689-713.

Möller, Johann $M$.

1991 "Knickrige Kulturnation. Was Wird aus der Kunst in den Neuen Bundesländern?" Frankfurter Allgemeine Zeitung, Nr. 299 (January 24), S. 26.

Nunnally, Jum C.

1978 Psychometric Theory, 2nd ed. New York: McGraw-Hill. 
Ocasio, William

1995 "The enactment of economic adversity: A reconciliation of theories of failure-induced change and threat-rigidity." In Larry L. Cummings and Barry M. Staw (eds.), Research in Organizational Behavior, 17: 287-331. Greenwich, CT: JAI Press.

Pfannkuch, Wilhelm

1962 "Organisationen in der Musik." In Allgemeine Enzyklopädie der Musik (Bd. 10): 204-220. Kassel: Bärenreiter-Verlag.

Pfeffer, Jeffrey, and Gerald R.

Salancik

1978 The External Control of Organizations: A Resource Dependence Perspective. New York: Harper \& Row.

Prieberg, F. K.

1982 Musik im NS Staat. Frankfurt: Fischer-Verlag.

Raynor, Henry

1978 The Orchestra. New York: Scribner's.

Rueschemeyer, Marilyn

1991 "State patronage in the German Democratic Republic: Artistic and political change in a state socialist society." Journal of Arts Management and the Law, 20: 31-55.

Salancik, Gerald R., and Jeffrey Pfeffer

1977 "Constraints on administrator discretion: The limited influence of mayors on city budgets." Urban Affairs Quarterly, 12: 475-498.

Scott, W. Richard

1987 Organizations: Rational, Natural, and Open Systems, 2nd ed. Englewood Cliffs, NJ: Prentice-Hall.
Shostakovich, Dimitri

1983 "Politics and artistic interpretation." In Jack B. Kamerman and Rosanne Martorella (eds.), Performers and Performances: The Social Organization of Artistic Work: 183-186. New York: Praeger.

Singh, Jitendra V., Robert J.

House, and David J. Tucker

1986 "Organizational change and organizational mortality." Administrative Science Quarterly, 31: 587-611.

Skocpol, Theda

1976 "Old regime legacies and communist revolutions in Russia and China." Social Forces, 55: 284-315.

Starbuck, William $\mathrm{H}$.

1976 "Organizations and their environments." In Marvin D. Dunnette (ed.), Handbook of Industrial and Organizational Psychology: 1069-1123. Chicago: Rand McNally.

Staw, Barry M., Lance E. Sandelands, and Jane E. Dutton

1981 "Threat-rigidity effects in organizational behavior: A multilevel analysis." Administrative Science Quarterly, 26: 501-524.

Stinchcombe, Arthur L.

1965 "Social structure and organizations." In James G. March (ed.), Handbook of Organizations: 142-193. Chicago: Rand McNally.

Thompson, James D.

1967 Organizations in Action. New York: McGraw-Hill.

$\rightarrow$ Tolbert, Pamela S

1985 "Institutional environments and resource dependence: Sources of administrative structure in institutions of higher education." Administrative Science Quarterly, 30: 1-13. $\rightarrow$ Tushman, Michael L., and Philip Anderson

1986 "Technological discontinuities and organizational environments." Administrative Science Quarterly, 31: 439-465.

Tushman, Michael L., and Elaine Romanelli

1985 "Organizational evolution: A metamorphosis model of convergence and reorientation." In Larry L. Cummings and Barry M. Staw (eds.), Research in Organizational Behavior, 7: 171-222. Greenwich, CT: JAI Press.

Weick, Karl E.

1993 "Organizational redesign as improvisation." In George P. Huber and William H. Glick (eds.), Organizational Change and Redesign: 346-379. New York: Oxford University Press.

Weineck, Isolde M. (ed.)

1985 Musik aus Deutschlands Mitte, 1485-1985. Bonn: Ferd Dümmlers Verlag.

Zimmer, Dieter E.

1990 "Wenn Humpty Dumpty zerbricht. Vorschlaege zur Rettung der Ehemaligen DDR-Kultur." Die Zeit, Nr. 52 (December 21).

$\rightarrow$ Zucker, Lynne G.

1977 "The role of institutionalization in cultural persistence." American Sociological Review, 42: 726-743.

1987 "Institutional theories of organization." In Annual Review of Sociology, 13 : 443-464. Palo Alto, CA: Annual Reviews.

\section{APPENDIX: Measures Derived from the Player Survey}

\section{Organizational Features of the Orchestra}

Integrity as an ensemble. The degree to which the orchestra operates as an intact, relatively stable ensemble, with clear and well-accepted norms of behavior. (8 items)

Orchestra structure: Task and composition. The degree to which the work of the orchestra is well-designed (i.e., the orchestra's tasks are challenging and feedback-rich) and the orchestra itself is well-composed (i.e., players have a sufficient level and mix of talent and experience for their collective work). (5 items) 


\section{Symphony Orchestras}

Player involvement and opportunities. The degree to which players have information and influence in the orchestra, share in its leadership, and have opportunities to improve their position within it. (8 items)

Adequacy of resources. The adequacy of the orchestra's facilities and material resources. (2 items)

\section{Single items retained:}

Recognition: "Excellent playing pays off in this orchestra."

Recruitment: "The orchestra's recruitment and audition process is fair and effective."

\section{Orchestral Process and Performance}

Quality of internal processes. The quality of the working relationships among orchestra members. (7 items)

Musical outcomes. The degree to which the orchestra is improving (vs. slipping) musically. (3 items)

\section{Single items retained:}

Finances: "Our orchestra is getting stronger and stronger financially."

Stability: "As an organization, our orchestra shows signs of falling apart." (reverse-scored)

\section{Player Motivation and Satisfaction}

General satisfaction. The respondent's overall satisfaction with his or her job and work. ( 3 items)

Internal work motivation. The degree to which the respondent is self-motivated to perform well (i.e., feeling good when having performed well and feeling bad when having performed poorly). ( 3 items)

Job involvement. A single item: "I live, eat, and breathe my job."

Satisfaction with specific aspects of the work environment:

Compensation ( 2 items)

Job Security (2 items)

Management (3 items)

Work Relationships (3 items)

Growth Opportunities (4 items)

\section{Behavior of the Music Director}

Direction-setting. The degree to which the music director sets a clear and engaging artistic direction for the orchestra. (5 items)

Organizational Initiatives. The degree to which the music director takes organizational initiatives (both internally, such as by working with management to improve the organizational structure or the recruitment process, and externally, such as by building community support or negotiating recording contracts). (7 items)

Coaching. The degree to which the music director makes himself or herself available to orchestra members and actively coaches individual players and sections. (5 items) 